\title{
Enactments of a "holistic approach" in two Danish welfare institutions accommodating young adults with offending behavior and drug use experiences
}

\author{
Maria Dich Herold, Cecilia Rand and Vibeke Asmussen Frank
}

\begin{abstract}
Maria Dich Herold, Cecilia Rand and Vibeke Asmussen Frank are all based at the Centre for Alcohol and Drug Research, Aarhus University, Aarhus, Denmark.
\end{abstract}

\begin{abstract}
Purpose - The purpose of this paper is to discuss how a "holistic approach" is enacted in two interventions accommodating the same target group, young adults with offending behaviour and drug use experiences, but offered in very different contexts, the Prison Service and the community. The aim is to show how enactments of a "holistic approach", although similar on paper, differ in welfare institutional practices due especially to organisational and structural conditions.

Design/methodology/approach - The paper is based on qualitative semi-structured interviews and written material from and about the two interventions.

Findings - Different enactments of a "holistic approach", due to organisational and structural conditions of the interventions, construct different possibilities for institutional identities. These insights could be useful to take into consideration when discussing prevention initiatives (in a broad sense) for young people with complex problems, including co-occurring offending behaviour and drug use experience.

Originality/value - Research with a focus on citizens with complex problems who do not comply with OR conform to standard welfare institutions are limited. The authors contribute to this literature by focussing on young adults with offending behaviour and drug experiences.
\end{abstract}

Keywords Young adults, Prevention, Denmark, Holistic approach, Complex problems, Institutional identities

Paper type Research paper

\section{Introduction}

Received 17 December 2018 Revised 25 March 2019 Accepted 26 April 2019

(C) Maria Dich Herold, Cecilia Rand and Vibeke Asmussen Frank. Published by Emerald Publishing Limited. This article is published under the Creative Commons Attribution (CC BY 4.0) licence. Anyone may reproduce, distribute, translate and create derivative works of this article (for both commercial and non-commercial purposes), subject to full attribution to the original publication and authors. The full terms of this licence may be seen at http:// creativecommons.org/licences/by/ 4.0/legalcode
A "holistic approach" (Danish: "helhedsorienteret indsats") has become a catchword in many different aspects of welfare policy in Denmark. In this paper, we discuss how a "holistic approach" is enacted in two different welfare institutions, which accommodate drug experienced youth in contact with the criminal justice system (CJS)[1].

In Denmark, the "holistic approach" as a concept appears in both social, health and legal rights laws (Harder and Nissen, 2013; Nissen and Harder, 2018; www.retsinformation.dk). One example is the Law on Social Services, which is the legal basis for welfare institutions that target marginalised or disabled citizens, including drug experienced young people. This law states that the starting point for all kinds of welfare institutional initiatives aimed at marginalised citizens has to be "coherent and holistic" (Law on Social Service, 1997), must take a point of departure in the citizen's everyday life situation, and must involve the citizen's own perspectives on what support is needed (Law on Social Services, Section III)[2]. Historically, a "holistic approach" emerged within social work in the 1960s in Denmark (e.g. Harder, 2013; Olesen, 2013) and elsewhere (e.g. Pyles and Adam, 2016). 
Nissen and Harder (2018) argue that particularly in the Danish context, a "holistic approach" has become a complex concept. In terms of definition, this concept has evolved in relation to societal and welfare state developments and therefore studying this approach is linked to developments in the welfare state, such as changes in social and health policies, legal changes, and implementation of new welfare services. A "holistic approach" is, in other words, not only written into Danish legislation and policies, but also stands out as a pivotal focus in contemporary Danish social work. Therefore, the intention to fully define what a "holistic approach" implies becomes an intricate task, particularly due to the complexity it entails and the diverse contexts (policies, research, social work interventions) in which it is applied (Nissen and Harder, 2018; Harder and Nissen, 2013), including that of interventions aimed at marginalised youth (e.g. Lau et al., 2017; Kjeldsen et al., 2015).

In addition to this, Nissen and Harder (2018) also argue that a "holistic approach", despite developments of different and varied definitions within social work, is basically an approach which aims at including a variety of levels and perspectives in the process of defining and seeking solutions to different kinds of social problems (Nissen and Harder, 2018, pp. 29-30). Following this, we will argue here that, while both interventions under scrutiny in this paper aim at helping their target group by applying a "holistic approach", their enactments of a "holistic approach" differ, in particular because of these interventions' organisational and structural differences (cf. Weinberg, 2001), being prison and community based respectively. Importantly, it is not our aim here to offer a new definition of a "holistic approach", but to analyse how the same welfare institutional concept is enacted in the context of two different welfare institutions. As part of this, we wish to discuss how these enactments may affect the young people enroled in these interventions, particularly by enabling them to take up different "institutional identities" (cf. Gubrium and Holstein, 2001; Järvinen and Mik-Meyer, 2003).

A "holistic approach" is thus "in vogue" and recommended from many sides, including international research literature (e.g. Menon and Cheung, 2018). This paper, however, adds to the literature on holistic approaches by focussing not on the definition or guiding principles of a holistic approach per se, but on the enactments of this concept in institutional practices. As part of this we argue that its meaning is (differently) enacted in (different) institutional set-ups, and that only by investigating these enactments do we know what a "holistic approach" can entail and thereby understand what it means for citizens enroled in these welfare institutions.

\section{Holistic interventions: formulating identities}

The two interventions in focus are offered in different settings. One intervention is offered in remand prison, the other in the community. In compliance with the Law on Social Services, the prison-based intervention describes itself as having a "holistic approach", for example in their accreditation report where they stress that the intervention is "holistic as well as differentiated according to the needs of the individual participants" (Accreditation Report, 2009, p. 7). The community-based intervention offers a variety of services aimed at the "social inclusion" of marginalised people (including drug-experienced youth in contact with the CJS). Similar to the prison-based intervention, they state explicitly that they have a "holistic approach", for example in working with citizens who are in need of assistance to navigate the "complex public welfare system" and in the ambition of constructing "coherence" between the different systems a citizen is enroled in (Community based intervention, 2016). In other words, both interventions follow legal demands and/or adopt social work perspectives referred to as a "holistic approach", and both interventions refer to a "holistic approach" as a particular way of understanding and approaching citizens with complex problems, i.e. citizens seeking help to solve multiple problems. First, this implies that none of these interventions approaches a particular problem "in isolation" (for example drug use), but instead is related to other challenges that the young person might have, and therefore also their wider everyday life (including for example offending behaviour, mental health problems, living in deprived areas, having a troubled family background). Drug use is therefore approached together with and in relation to the other problem(s) that the citizen might face, and it is recognised that helping the citizen with other aspects of their life can have a positive effect on reducing or ending drug use. Second, both interventions aim to approach and construct solutions to these multiple problems by establishing inter-sectorial co-operation between, for example, the Prison Service, municipal drug treatment, social benefit services, educational institutions and to make these systems co-operate in order to help their young participants. 


\section{Formulating institutional identities}

Welfare institutions are in general characterised by offering particular solutions to particular problems (e.g. Jöhncke et al., 2004), and therefore also by engaging in the construction of particular problem understandings, often (but not only) in relation to citizens who are seen as "problematic" or "distressed", for example due to drug use, unemployment, or homelessness (e.g. Järvinen and Mik-Meyer, 2003, 2012). Thus, to become enroled as clients in a welfare institution, citizens in need of help have to subject themselves to the understandings and solutions that welfare institutions offer, and as part of this to take on "the identities that the institutions formulate and promote" (Gubrium and Holstein, 2001, p. 11). As this indicates, one line of welfare institutional research has focussed, precisely, on how welfare services are not merely neutral "problem solvers" but also how they, as part of addressing the issues which the citizens need help to handle, are constructing "institutional identities" for their clients (e.g. Gubrium and Holstein, 2001; Järvinen and Mik-Meyer, 2003; Järvinen and Gubrium, 2016). These institutional identities emerge through subjectification processes that play out between the norms, values and organisational structures that shape how (welfare) institutions define and solve the problems they aim at, and the biographical particulars and specific social conditions of the citizen (Gubrium and Holstein, 2001). "Who one is", in other words, becomes a public concern, and "the self" a social structure which is constantly constructed in and through the different discursive environments of everyday life. This includes, but is not restricted to, the various (welfare) institutional settings, which for example drug experienced youth in contact with the CJS are subjected to. However, as Gubrium and Holstein (2001) note, "the possibilities for who we might be as troubled persons are not set in stone, but vary across time and social circumstance" (p. 14). As such, the same person may be identified differently in different welfare institutions.

Another, but related, line of welfare institutional research which is relevant for our analysis focusses particularly on citizens who embody a variety of problems, and who, because of this, are simultaneously enroled in several services, such as for example drug treatment (because of drug problems), psychiatric treatment (because of psychiatric problems), and prison services (because of offending behaviour). A specific mode of interest in this line of research revolves around the observation that welfare services often have difficulties with handling such "complex problems", and, moreover, that the problem understandings and solutions of these various services do not necessarily match (e.g. Nygaard-Christensen et al., 2018; Bjerge et al., 2018; Johansen, 2018). So, despite the fact that welfare institutions in Denmark, on a national level, answer to the same laws and policies, for example by being obliged to provide "holistic" solutions to citizens with social problems, varying institutional "set ups" mean that these solutions are possibly enacted in a variety of ways (cf. Lipsky, 1980). Such variations, for example in the form of organisational structure, institutional values and wider institutional embedding, enable different - and not necessarily congruent - "institutional identities" for their clients.

Taken together, in relation to our analysis of welfare institutional enactments of "holistic approaches" aimed at drug experienced youth in contact with the CJS, these perspectives enable us to explore how a prison-based intervention and a community-based intervention - both approaching their clients by means of "holistic" efforts - in practice formulate quite different identities for their clients. It is the emergence of these institutionally constituted identities that we wish to explore in our analysis, in order to be able to discuss their implications in relation to drug use prevention for young people in contact with the CJS. Following Gubrium and Holstein (2001), we will pay analytical attention to what is locally available in the two interventions in terms of identity resources (e.g. problem understandings; organisational barriers); however, in this paper we will not focus on how processes of self-construction then unfold among the clients of these institutions. Our aim here is merely to highlight the contours of available identities within the discursive environments that define our two chosen interventions, whilst the particulars of how these institutional identities are "put into practice" by the young participants is left for later analysis (cf. Gubrium and Holstein, 2001, p. 16). Before presenting our analysis, we will first describe our methods and data in more detail.

\section{Data and methods}

The two interventions under scrutiny here accommodate drug experienced young people, who due to different forms of offending are presently in contact with the Danish CJS, either because they are in 
custody, are serving a prison sentence or are serving a community sentence. These two interventions, however, differ in significant ways. One intervention is a custody prison-based pre-treatment programme aimed at improving their participants' motivation to continue drug treatment after they have received their sentence, whether in prison or non-custodial. A primary target group of this intervention is young adult remand-prisoners (pp. 18-25) who are motivated to participate in drug treatment initiatives. Being located in the prison setting, this intervention is subjected to the Prison Service's rules and regulations. Among other things, this includes zero tolerance towards drug use, participants' transfer to a prison when sentence is passed (acquitted), and prison reward/punishment systems, for example in the form of receiving "points" for attending drug treatment or in the form of restrictions if prison regulations are compromised. The intervention is funded and run by the Prison Service. As a publicly funded initiative, the prison-based intervention is obliged to monitor their clients, and to use evidence based methods in order to receive accreditation and to live up to national quality standards for social interventions aimed at prisoners in need of drug treatment (www.kriminalforsorgen.dk)[3]. The other intervention is a community-based social programme with an explicit focus on the social inclusion of vulnerable citizens of all ages with a broad range of challenges. Thus, their target group includes (but is not restricted to) young people with cooccurring drug use experiences and offending behaviour. This intervention is a voluntary, non-profit organisation, which is primarily based on private donations. Being a voluntary organisation, the intervention is not obliged to monitor its participants, to use evidence-based method, or subjected to quality standards and accreditation. However, the intervention has to deliver effective results, have a high ethical standard, and be a transparent organisation in order to continuously get private funds[4].

Our analysis of what identity resources are locally available in the two interventions is based empirically on publicly available written material from these two interventions, as well as qualitative interviews with professionals working in these interventions. This empirical combination enables a top-down analytical focus on purposes and aims of the interventions on a local level; how these purposes and aims are related to wider, national policies around services aimed at citizens with "complex problems"; and finally - particularly by means of interviews with professionals - an insight as to how official purposes and aims are enacted "on the ground". Written material includes formal descriptions of the interventions, stemming from evaluation reports, brochures, newspaper articles and webpages. We interviewed nine professionals in all. Interviews are semi-structured individual interviews with five professionals and two interviews with two professionals at the same time (i.e. four professionals). Three individual interviews were made with professionals from the prison-based intervention and two individual interviews with professionals from the community-based intervention. We used a semi-structured interview guide focussing on different themes, including professionals' perceptions of the intervention in focus; the role of quality standards in the intervention; and perceptions of drug use trajectories among their young clients. All individual interviews were recorded and transcribed verbatim. The two interviews in which we interviewed two professionals together were not recorded, but two of the authors were present in the interview situation, and extensive notes were taken during the sessions. All professionals were practitioners working on a daily basis with the young adults. They have various social pedagogical and therapeutical backgrounds and training, and several years of experience in working with young people in drug-reducing interventions. In the prison- and community-based interventions, there were six and eight employed professionals, respectively. In both interventions there were other kinds of professionals as well, e.g. staff. We only interviewed employed professionals. We recruited interviewees with different backgrounds and experiences in order to secure different perspectives and experiences from the two interventions. All professionals signed informed consent forms and all professionals are anonymised[5]. For anonymity purposes, we refer to professionals with a number in the analysis, e.g. "professional 1", and we refer to all as "s/he" or "they". All transcribed interviews were coded using Nvivo11. For the present article we used the codes "holistic approach", "co-operation" and "problem understanding (of the client)". We incorporated the extensive notes from the two interviews where two professionals were interviewed together.

\section{Analysis}

In the analysis we focus on the following issues: drug use and how this "problem" is understood as part of a broader nexus of "complex problems" in the two interventions (problem understanding); 
the solutions to this issue, particularly in the form of inter-sectorial co-operation practised in the interventions; and the barriers that the interventions are faced with in terms of delivering "a holistic approach". Throughout the three sections we include analyses of how these issues have an effect on the formulation of the "institutional identities" that are constructed in the interventions.

\section{Young people with complex problems}

Professionals interviewed from the two interventions have a similar understanding of the young people they are working with: they are young people with complex problems who do not fit into existing welfare institutions. Professional 1 from the community-based intervention for example says:

The citizens who come here are so different that it is hard to put them in a particular pigeonhole. They do not match the categories that exist in the public services.

While this is the general point of departure for the community-based intervention, the aim of the prison-based intervention is, in particular, to address drug use and offending behaviour. Despite this, professionals in the prison-based intervention, too, understand their participants as young people with complex problems. They see them as young people who do not follow the expected developmental pathways, for example in terms of obtaining an education:

$[\ldots]$ they are in an extremely stressful situation, and under pressure [...] but they also deal with a lot of different things. For example, having left school too early and not finished with an exam. They are very young when we see them here in our intervention, 18, 19, or 20 years old (Professional 3, Prison-based intervention)

Professionals in this intervention emphasise that drug use is not a delineated issue, but part of a more complex nexus of problems such as offending behaviour, damaged social and family relationships, and their general everyday milieu, as for example being on social security, being homeless and having broken educational trajectories:

I definitely view drug misuse as a symptom of their problems. It might not always be the case, but it usually is. Those who are easiest to help are those who do not carry a big load of other issues [...] They are not as fixed in their habits and ways of life. I often think of drug misuse as a symptom, but with a persistent negative effect (Professional 1, Prison-based intervention).

Thus drug use is seen as intrinsically related to the often deprived backgrounds of their clients. It is a symptom of "deeper" problems, yet as an unfortunate way to handle them, which has, or will, become problematic in itself. In accordance with this problem understanding, professionals in the prison-based intervention - if this fits the young participant's wishes - seek to focus broadly on their life situation, and not merely on their use of drugs.

In addition to having similar views on the complexity that marks their participants' situations, professionals in both interventions share the understanding that the Danish welfare system is too difficult to navigate for their young participants, and that they, as professionals who work with this particularly "system-vulnerable" group of young people, therefore need to assist them on this matter:

One thing is that they have to show up in drug treatment alone, which for some can be quite overwhelming. And if they, on top of this, experience that when they actually do show up, they are not getting the help that they need, and maybe they are put on hold [...] then it's easily like, "bye bye, I'll handle these things on my own", right. This is often what we hear when we follow up on our participants who are released to freedom (Professional 2, Prison based intervention).

Professionals in the community-based intervention describe similar experiences of "the system's" complexity which make it difficult for their young participants to get the help that they need, and emphasise that changes in who the young person is in contact with when attending the municipal social services create frustrations:

I hear often that the young people for example get a new social worker, that they then have to start over again, and that the social worker has not read our young person's file. What they also say with these experiences is that they do not feel that they are taken seriously or that they simply feel neglected - "the social worker did not understand what I said" or "she didn't care at all about me" (Professional 2, Community-based intervention). 
To sum up, both interventions have very similar problem understandings vis-à-vis the young people they are working with. They see them as young people with complex problems, who are easily lost in the complexity of the welfare system, and, following from this, that a "holistic approach" with a main focus on inter-sectorial co-operation is an important part of the solution to their problems. On this "ideological" level, then, the institutional identities, which are constructed, revolve partly around issues of "vulnerability" in the sense that these are young people who are not only seen as vulnerable in terms of drug use and other forms of "problem behaviour", but also in terms of not getting the help that "the system" is obliged to provide. But, at the same time, due to the "holistic" ambition of including participants' own perspectives, they also become subjected to the notion that they are "experts" - not in "system navigation", but on their own needs (cf. Frank and Bjerge, 2011). In spite of these similarities, however, the two interventions enact "a holistic approach" through inter-sectoral co-operation in very different ways, particularly due to organisational circumstances. As we will show in the following, this results in constructions of very different institutional identities.

\section{Enactments of inter-sectorial co-operation}

Starting with the prison-based intervention, professionals here focus on how they can establish contact with other relevant welfare services in their participants' home municipality, or, alternatively, with interventions in other prison institutions, if the young person is transferred after their sentence is passed:

Everytime a participant is transferred I contact the drug treatment intervention - either in another prison or in the community. In the community, it is more difficult. We give the contact details to the participant and often call to see whether he showed up. Occasionally, we also help set up a meeting. But it is up to the young person to get in contact with the particular service if he wants to continue in drug treatment (Professional 2, Prison based intervention).

Professionals thus describe how making connections for their client to other drug-treatment institutions is a central aspect of their work. In these cases, they seek to co-operate with other welfare services that the young person would possibly benefit? from being enroled in. Importantly, however, this is done on behalf of the young person - and not, as we shall see with the community-based intervention, together with them. As professional 1 in the prison-based intervention states: "It is our job to give them contact details, help them knowing where to go [...] but we can only be the link". Thus, in this intervention, the professionals make the phone calls and write the e-mails, or in other ways line up welfare institutional possibilities for their young participants to take up later on. As such, professionals in the prison-based intervention create "links", "paths" and "build bridges". However, due to the circumstance that this intervention is located in a prison setting, the young person is "stuck" in his cell while these future-oriented processes take place. Nonetheless, it becomes his responsibility to follow the paths which were laid out for him upon release or transfer. Arguably then, in addition to being subjected to mixed notions of "vulnerability" and "expert" on a "holistic-ideological level", the prison-based intervention's participants are furthermore subjected as "non-active" on a "holistic-enacted" level. The professionals act on behalf of them. This, however, is at least to some extent because this intervention is firmly bound by the circumstance that, while being in drug-pre-treatment, their participants are unavoidably also prisoners. Consequently, the "institutional identities" which are formulated for these young people with complex problems are arguably multi-dimensional. They become both a mix of "vulnerable" and "experts" (vis-à-vis the ideal interpretation of "a holistic approach") but also, and at the same time, "non-active", but still expected to act as an empowered citizen who is able to follow these laid out paths upon release or transfer (vis-à-vis how the "holistic approach" is actually enacted). The solution (inter-sectoral co-operation) to the problem (complex problems, including drug use) is thus far from straightforward. Importantly, this added complexity in terms of enacting a holistic approach in a remand prison does not stem from un-engaged or un-skilled professionals, but from the fact that this intervention is both bound to, restrained by, and exists due to the prison system.

Even though the community-based intervention has a broad target group (marginalised citizens in need of help) as compared with the prison-based intervention, their participants are primarily young people with complex problems, including simultaneous drug use and offending behaviour. 
Thus, already prior to their participation in this intervention, participants are subjected to multiple institutional identities formulated by the different institutions that they take part in. One of the community-based intervention's main priorities is exactly to assist their young participants in navigating in and between these institutions, their rules, regulations and (identity related) requirements. As such, this intervention, on an institutional level, positions itself, not as an "integrated part" of the Danish welfare system, but as being somewhat in opposition to the established system, albeit with enough know-how and insight to assist their participants in becoming knowledgeable about this system themselves. In the community-based intervention, inter-sectoral co-operation is thus enacted quite differently than in the prison-based intervention. Overall, professionals in this intervention do this by "walking the steps together with" the young person:

We simply start by asking what the user dreams of. What is it he or she wants? Whatever it is - contact with the system, getting different systems to talk to each other, or get a doctor's appointment - we start there. We help the citizens to walk the steps, make the phone calls, and set up a meeting with the social worker or the doctor, or set up a network meeting with relevant professionals from different systems. Get a good co-operation going, and help our participant to get on from there. This can be quite overwhelming if you are a citizen in a vulnerable situation [...]. We don't do it for them, but walk the steps together with them. One day they will be able to do it themselves (Professional 1 , Community-based intervention).

Professionals in this intervention thus organise, set up and accompany their participants to meetings and appointments, whether they have been summoned to a meeting, for example in the Prison Service, or they voluntarily want to get in contact, for example, with social services, the psychiatric system or an educational institution. This enactment is, at least partly, informed by the knowledge that many of their participants have experienced a great deal of difficulty with not being met by "the system" in a proper way when they seek contact on their own, experiences of being turned down or denied help, and that they therefore "hate" the system. Professionals seek to assist the young person to engage with the system in a way that is helpful for them:

We begin, because we know it is very difficult for them to pick up the phone. One client has experienced, again and again, not being able to get through to the right person. Then we are her representative (Professional 1, Community-based intervention).

As such, professionals in this intervention become "representatives" or "mentors" for the young person. They aim to "navigate the system" together with them and to "teach them how to manage or handle how the system is structured":

I often think of our job as a translation job. We are clearly on the citizen's side, but try to translate what the reason for e.g. not getting a service is. That it is about resources or that our user does not fit the target group of a certain intervention. If it is explained properly, we often experience that the user accepts this. Especially if it is about economic resources. Translating between the system and our users can avoid a lot of conflicts between the user and the system (Professional 1, Community-based intervention).

The professionals thus support the process of "making things happen" by engaging in such things together with them, by supporting them with their presence whenever needed, and as such the professionals scaffold the client's way around the system. For good reasons, since this is a community-based intervention, the professionals are able to accompany their participants to other services. In terms of institutional identities, the young participants in these contexts thus become an "apprentice" or a "mentee" who is obliged to "learn" from the professionals, i.e. how to navigate in the different welfare systems. They are required to be actively engaged in their own process, and as part of this, required to learn about how the welfare system works, how it is organised, and how best to accommodate to it.

To sum up, while the two interventions share common ground on an ideological level particularly in terms of how they portray their young participants as, at the same time, "vulnerable", "experts" on their own situations, and in need of inter-sectorial help, they do also differ. As we have aimed to show, differences are, at least partly, based on the fact that the interventions are embedded very differently, both in relation to the wider Danish welfare institutional landscape and in terms of internal organisation and structure. Whilst the prison-based intervention must submit to the Prison System's rules and regulations, which then affect the institutional identities they come to formulate for their clients, the community-based intervention is able to engage their participants and teach them how to get the help they need. In consequence, the prison-based intervention is obliged to act on behalf of the young 
person as part of their inter-sectorial efforts, while the community-based intervention is able to act together with their participants. As we have argued, these organisational differences hence enable rather different institutional identities. Enacting a holistic approach within a remand prison simply gives professionals very different possibilities, and serves a different purpose, to working in the community. This, however, does not mean that the professionals in the community-based institution are not faced by any challenges or barriers when doing their job - challenges which also affect how institutional identities are formulated. In the final analytical section, we will focus particularly on structural barriers, and what they consist of in each of the two interventions.

\section{Structural barriers}

Professionals in both interventions experience structural barriers in their processes of enacting a "holistic approach". As suggested above, in the prison-based intervention structural barriers are predominantly related to their embeddedness in the Prison Service, primarily that they are obliged to submit to overall prison rules and regulations, for example that participants are regularly transferred without notice. Consequently, the prison-based intervention's aim of creating pathways to drug treatment in other prison settings through co-operation and knowledge exchange is easily compromised:

Many of the drug treatment offers in prisons have long waiting lists. So, a young person can be transferred from here to a prison, but cannot enter drug treatment before there is a vacant place. Also, sometimes they are not transferred to the prison with the drug treatment offer that would suit them best. Safety and filling up places in prisons take priority (Professional 1, Prison-based intervention).

In addition to internal structural barriers, the prison-based intervention is dealing with barriers that emerge between themselves, i.e. a prison-based drug intervention, and municipal or private interventions located in the community. This gap becomes a significant structural barrier particularly when professionals seek to construct and support their participant's future treatment participation through inter-sectorial co-operation with partners outside the prison setting. It is, in other words, difficult to build and maintain a preferred level of co-operation between the "closed prison world and the world outside", as professional 2 says:

We simply have a challenge in terms of getting them [municipal treatment providers] to come in here for meetings, and to make them trust our assessments of our participants. They want to make their own visitations/assessments in order to evaluate whether they are entitled to treatment despite that we know they are [...] Sometimes it feels like we lose our participants in the process. [...] It is in the translation it gets difficult, even if they become drug free in here.

As the quote exemplifies, "bridge-building" between the prison and the community setting as part of securing continuation of help for a participant can be highly complicated. First, because meetings with contact persons from community services can be difficult to establish, which means that the young participant does not get to know these professionals, and vice-versa. Second, because some of these welfare services, here exemplified by community drug treatment, are not comfortable with the intervention's assessments, but want to make their own. Arguably, this results in a sense of "institution-level stigma", which might possibly strengthen the marginalisation that already marks the young people who the prison based intervention is accommodating, for one thing, because it complicates further the already complicated process of securing them the help they need. Another, and similar, structural barrier described by the prison-based intervention is that remand prisoners are put on "standby", not only in terms of being "stuck" in their cells, but also by the municipality, as suggested in the quote below. This situation also poses problems for the professionals' inter-sectorial efforts. Professional 1 explains:

When I am dealing with a participant who will be homeless after release, I have to refer them to a youth-shelter. This is the only way to ensure them a place to be after release, as they are not allowed to be on a housing waiting list while they are in here [prison]. The system simply won't deal with them before they are contributing actively to society again. So, in order to handle this situation, I refer them to a youth-shelter [...]

\section{And continues:}

So, when I refer them to a youth-shelter, I can also phone the municipal social worker and say "hey, try and phone the shelter, he is probably there" and then the contact is made. 
This exemplifies how professionals are often not able to initiate the support that they know would benefit their participants most. Instead, they have to make alternatives by finding the right "loopholes" in the system (cf. e.g. Lipsky, 1980; Nygaard-Christensen et al., 2018).

Together, the above examples arguably show that the aims of the prison-based intervention of creating "pathways" for their young person to follow upon release or transfer are easily disrupted by a variety of structural barriers which in most cases are related to the fact that this is a prison-based initiative. Importantly, this does not mean that the intervention is ineffective or redundant. On the contrary, as we see it, it stresses the importance of their existence while also informing us about the manifold difficulties that emerge when systems' values and norms collide. As part of this, what, from a social work perspective, serves these young people best is very easily thwarted by the hierarchal relationship that exists between this initiative and the correctional purposes of the prison service, and which, in terms of prevention of future "problematic behaviour" (drug use, offending), may even be counterproductive (cf. Christiansen, 2018).

Shifting focus to the community-based intervention, an important structural barrier experienced by the professionals in enactments of inter-sectoral co-operation by "walking the steps together with the client" relates to the fact that different welfare systems have different rules and policies. The inconsistencies that emerge from this are often difficult for young people? who are simultaneously enroled in different welfare institutions. For example, if a young person is on parole with an electronic tag, this means that $s /$ he has to be drug free and deliver negative urine tests. However, this does not necessarily comply with the norms of the drug treatment that the young person might also be enroled in, in so far as reduction of drug use and harm reduction is the focus:

They are tough in the Prison Service. He is on parole with an electronic tag. He got a chance to serve his sentence on milder conditions. But this means no drugs and negative urine tests. If not, he will be sent back in prison. But they don't ask why he uses drugs. [as is the case in drug treatment]. They don't focus on co-operating with us, for example, or with the drug treatment services. When he got the electronic tag off, he was back on drugs. So, we see it as our job to facilitate cooperation between drug treatment services, the Prison service and the young person (Professional 1, Community-based intervention).

In this example, the professional points to differences in norms, values and rules in different welfare systems, but also to how Prison Service rules (always) takes precedence over other welfare services' way of dealing with these young people (cf. Frank and Kolind, 2008). Thus, as is also the case for professionals in the prison-based intervention, professionals in the community-based intervention must struggle to knit together the best possible co-operation between welfare services. The experience of navigating between several sets of norms and values, especially when one takes priority over the others (here exemplified with the Prison Service's culture and regulations around security, order, zero-tolerance and sanctions), is also discussed in both national and international literature (see, e.g. Goldhill, 2016; Frank and Kolind, 2008).

Another example of how barriers to inter-sectoral co-operation emerge from inconsistent problem understandings between two (or more) welfare institutions, is described by professional 2 , when s/he talks about working with young participants, who are enroled in both the psychiatric system and in community drug treatment:

I am a lay representative for a young person who needs assessment at the psychiatric hospital. The young person also has a problematic use of drugs. Then the psychiatric hospital will not assess him and he cannot get psychiatric treatment. They say: "stop your drug misuse and then you are welcome here again". The young person "falls between two stools". It makes me angry. It is not possible for these young people to take one thing at a time: first get out of drug misuse, then be treated for ADHD, borderline or anti-social behaviour. These things will always overlap. And we haven't even talked about offending behaviour and being in contact with the criminal justice system yet.

The quotation emphasises how the solution to a problem can only be implemented under particular circumstances, or more specifically that psychiatric treatment can only be offered to young people without an ongoing use of drugs. These barriers are not only experienced by professionals in the community-based intervention, but are a general challenge for many professionals, as for example Johansen (2018) emphasises. But particularly in the context of our intervention, this pattern means that the ambition of teaching their participants how to navigate between different "institutional identities" becomes unachievable - simply because the inconsistencies, in some cases, seem impassable. 


\section{Conclusion: implications for prevention?}

Our aim with this paper has been to discuss how a "holistic approach" is enacted in two interventions accommodating the same target group, young adults with offending behaviour and drug use, but offered in very different contexts, the Prison Service and the community. Our ambition has been to show how enactments of a "holistic approach", although similar on paper, differ in welfare institutional practice due especially to organisational and structural conditions. Our argument has been that different enactments of a "holistic approach" construct different possibilities for institutional identities. These insights, we will argue, could be useful to take into consideration when discussing prevention initiatives (in a broad sense) for young people with complex problems, including co-occurring offending and drug use.

Both interventions under scrutiny in this paper are unique compared to other welfare interventions offered in prisons and in the community to young adults in Denmark. While there are pre-treatment offers in other remand prisons in Denmark, none is as elaborate as the one presented here. The community-based intervention is unique in accommodating all marginalised citizens in need of help (not focussing on a particular "problem", e.g. drug use or homelessness), and also in performing lay representative work for their participants. The two interventions in focus are therefore "innovative" rather than "standard" cases of what else is offered to this target group in Denmark. However, in terms of establishing new and different initiatives targeting this group of young people, it is in any case important to keep in mind the conditions and circumstances within which such interventions are operating. While it is valuable to implement "holistic approaches" when dealing with this target group, it is, at the same time, necessary not only to focus on policy and social work ideas but also on the extent to which they are possible to enact in differently organised and institutionally embedded welfare institutions.

In the analysis we have shown how the two interventions in focus here have similar problem understandings, their participants being young adults with complex or multiple problems who do not fit into one welfare institution, but are or should preferably be enroled in several institutions in order to get the help that they need. The interventions also share the notion that the Danish welfare system forms a complex landscape that can be difficult to navigate, and that the young people therefore easily become "system-vulnerable". Consequently, facilitation of inter-sectoral co-operation serves as an important technique in how these interventions enact a "holistic approach". Furthermore, we have argued that a "holistic approach" is considered to be important, both in Danish welfare policy and in the social work literature. As such, a holistic approach is "in vogue" and recommended from many sides, including international research literature (e.g. Menon and Cheung, 2018). However, our data also suggest that what seems a sensible and recommended idea might not necessarily be an easy task to implement "on the ground". Due to organisational structures, institutional values and wider institutional embedding, professionals have particular constraints when enacting a "holistic approach", which furthermore co-constitute the institutional identities that are formulated for the young people who participate in these interventions. Moreover, we did also emphasise how rules and regulations in particular welfare institutions take precedence over others (e.g. the Prison Service over drug treatment, psychiatric treatment over drug treatment). Therefore, the young participants have to comply with different institutional identities when enroled in several welfare institutions. Enacting a "holistic approach" towards young people with complex or multiple problems is, therefore, always conditioned by the contexts that both the young person and the intervention are part of. This, we argue, is necessary to take into account when discussing future interventions aimed at this target group.

While this paper has focussed on professionals' perspectives and experiences of a holistic approach, we would recommend that future research not only keep exploring enactments of a holistic approach from professionals' perspectives, but also explore how possible institutional identities interact with citizens' own sense of their identity formation and notions of agency in tackling the issues they face.

\section{Notes}

1. The article is part of the project 768162/EPPIC, which has received funding from the European Union's Health Programme (2014-2020). The content of this report represents the views of the authors only and is their sole responsibility; it should not be considered to reflect the views of the European Commission 
and/or the Consumers, Health, Agriculture and Food Executive Agency or any other body of the European Union. The European Commission and the Agency do not accept any responsibility for use that may be made of the information it contains. See also www.eppic-project.eu

2. See Frank and Bjerge (2011) for further information on user involvement in social welfare services in Denmark.

3. The quality standards include for example the use of evidence-based methods, monitoring and annual evaluation of whether the intervention has reached its goals.

4. For detailed descriptions of the two interventions see Herold and Frank (2018).

5. The research project has been approved by the Danish Data Protection Agency.

\section{References}

Accreditation report (2009), Prison based intervention, Københavns Fængsler, Københavns Kommune, Projekt Over Muren, København.

Bjerge, B., Eule, T.G. and Elmholdt, K.T. (2018), "Researching organizational imbrications and interstices: a qualitative gaze on how mundane public administration works", Qualitative Studies, Vol. 5 No. 2, pp. 49-56.

Christiansen, B.H. (2018), "Massiv kritik: straf til børn bekæmper ikke kriminalitet”, Socialrådgiver foreningen, available at: www.socialraadgiverne.dk/straf-til-boern-bekaemper-ikke-kriminalitet/ (accessed 14 December 2018).

Community based intervention (2016), "Fundamentet: Sociale forandringer i bæredygtigt fællesskab" (Brochure printed by Intervention B).

Frank, V.A. and Bjerge, B. (2011), "Empowerment in drug treatment: dilemmas in implementing policy in welfare institutions”, Social Science \& Medicine, Vol. 73 No. 2, pp. 201-8.

Frank, V.A. and Kolind, T. (2008), "Dilemmas experienced in prison-based cannabis treatment - drug policy in Danish prisons", in Frank, V.A., Bjerge, B. and Houborg, E. (Eds), Drug Policy - History, Theory and Consequences, Aarhus Universitetsforlag, Aarhus, pp. 61-86.

Goldhill, R. (2016), "Reflections on working with vulnerable women: connecting, cans of worms, closures and coping”, British Journal of Social Work, Vol. 46 No. 5, pp. 1336-53.

Gubrium, J.F. and Holstein, J. (2001), Institutional Selves: Troubled Identities in a Postmodern World, Oxford University, New York, NY.

Harder, M. (2013), "Helhedssyn - et begrebs udvikling", in Harder, M. and Nissen, M.A. (Eds), Helhedssyn i socialt arbejde, Akademisk Forlag, København, pp. 27-46.

Harder, M. and Nissen, M.A. (Ed.) (2013), Helhedssyn i socialt arbejde, Akademisk Forlag, København.

Herold, M.D. and Frank, V.A. (2018), Description of Innovative Approaches Including Professionals' and Young Peoples' Perspectives, Centre for Alcohol and Drug Research, Aarhus, available at: https://pure.au.dk/ portal/files/127570534NP5_Danish_National_Report_2018.pdf

Järvinen, M. and Gubrium, J.F. (Eds) (2016), Turning Troubles into Problems: Clientization in Human Services, Routledge, Abingdon.

Järvinen, M. and Mik-Meyer, N. (Eds) (2003), At skabe en klient: institutionelle identiteter i socialt arbejde, Hans Reitzels Forlag, København.

Järvinen, M. and Mik-Meyer, N. (Eds) (2012), At skabe en professionel: ansvar og autonomi i velfærdsstaten, Hans Reitzels Forlag, København.

Johansen, K.S. (2018), "Treatment of dual diagnosis in Denmark: models for cooperation and positions of power", Qualitative Studies, Vol. 5 No. 2, pp. 125-39.

Jöhncke, S., Svendsen, M.N. and Whyte, S.R. (2004), "Løsningsmodeller: Sociale teknologier som antropologisk arbejdsfelt”, in Hastrup, K. (Ed.), Viden om verden: En grundbog i antropologisk analyse, Hans Reitzels Forlag, København, pp. 385-407.

Kjeldsen, L., Frederiksen, N.Ø., Murphy, M.V. and Glad, A. (2015), Gadeplan. Slutevaluering af 17 indsatser under puljen for helhedsorienteret gadeplansindsats, Center for Boligsocial Udvikling, Hivdovre. 
Lau, C.B., Delica, K.N. and Andersen, H.L. (2017), En håndholdt indsats: Praksisnære erfaringer fra Lolland-Falster - om potentialer og vanskeligheder ved indsatser, der understøtter sundhed, trivsel og udviklingsmuligheder i sårbare unges liv, Roskilde Universitet, Roskilde.

Law on Social Service (1997), available at: www.retsinformation.dk/forms/R0710.aspx?id=202239

Lipsky, M. (1980), Street-Level Bureaucracy. Dilemmas of the Individual and Public Services, Russel Sage Foundation, New York, NY.

Menon, S.E. and Cheung, M. (2018), "Desistance-focused treatment and asset-based programming for juvenile offender reintegration: a review of research evidence", Child and Adolescent Social Work Journal, Vol. 35, pp. 459-76.

Nissen, M.A. and Harder, M. (2018), "Helhedsorienteret arbejde med udsatte familier: - hvor kom det fra og hvorfor er det stadig vigtigt?", in Willumsen, A.M. (Ed.), Helhedsorienteret socialt arbejde med udsatte familier, Akademisk Forlag, København, pp. 21-35.

Nygaard-Christensen, M., Bjerge, B. and Oute, J. (2018), "A case study of casework tinkering", Qualitative Studies, Vol. 5 No. 2, pp. 57-71.

Olesen, S.P. (2013), "Helhedssyn nedefra - et bottom up-perspektiv på socialt arbejde", in Harder, M. and Nissen, M.A. (Eds), Helhedssyn i socialt arbejde, Akademisk Forlag, København, pp. 213-37.

Pyles, L. and Adam, G.J. (Ed.) (2016), Holistic Engagement: Transformative Social Work Education in the 21st Century, Oxford University Press, New York, NY.

Weinberg, D. (2001), "Self-empowerment in two therapeutic communities", in Gubrium, J.F. and Holstein, J.A. (Ed.), Institutional Selves - Troubled Identities in a Postmodern World, Oxford University Press, Oxford, pp. 84-104.

\section{Web references}

www.eppic-project.eu

www.fundamentet.org

www.koebenhavnsfaengsler.dk

www.retsinformation.dk

www.steffenrasmussen.dk

\section{Further reading}

Annual Report, Prison based intervention (2016), Kriminalforsorgen, København.

Binswanger, I.A., Nowels, C., Corsi, K.F., Long, J., Booth, R.E., Kutner, J. and Steiner, J.F. (2011), "'From the prison door right to the sidewalk, everything went downhill,' a qualitative study of the health experiences of recently released inmates", International Journal of Law Psychiatry, Vol. 34 No. 4, pp. 249-55.

Project Plan, Prison based intervention (2007), "Københavns Fængsler \& Københavns Kommune", København, available at: https://file:///C:/Users/au595544/Downloads/Projektplan\%20Projekt\%200ver\%20 Muren.pdf; https://docplayer.dk/1308757-Projektplan-projekt-over-muren.html

Stiftstidende (2017), "Fundamentet styrker fællesskabet”, 20 May, available at: https://stiften.dk/aarhus/ Fundamentet-styrker-faellesskabet/artikel/454634 (accessed October 2018).

\section{Corresponding author}

Vibeke Asmussen Frank can be contacted at: vaf.crf@psy.au.dk

For instructions on how to order reprints of this article, please visit our website:

www.emeraldgrouppublishing.com/licensing/reprints.htm

Or contact us for further details: permissions@emeraldinsight.com 